\title{
A MULHER EXECUTIVA E SUAS RELAÇÕES DE TRABALHO
}

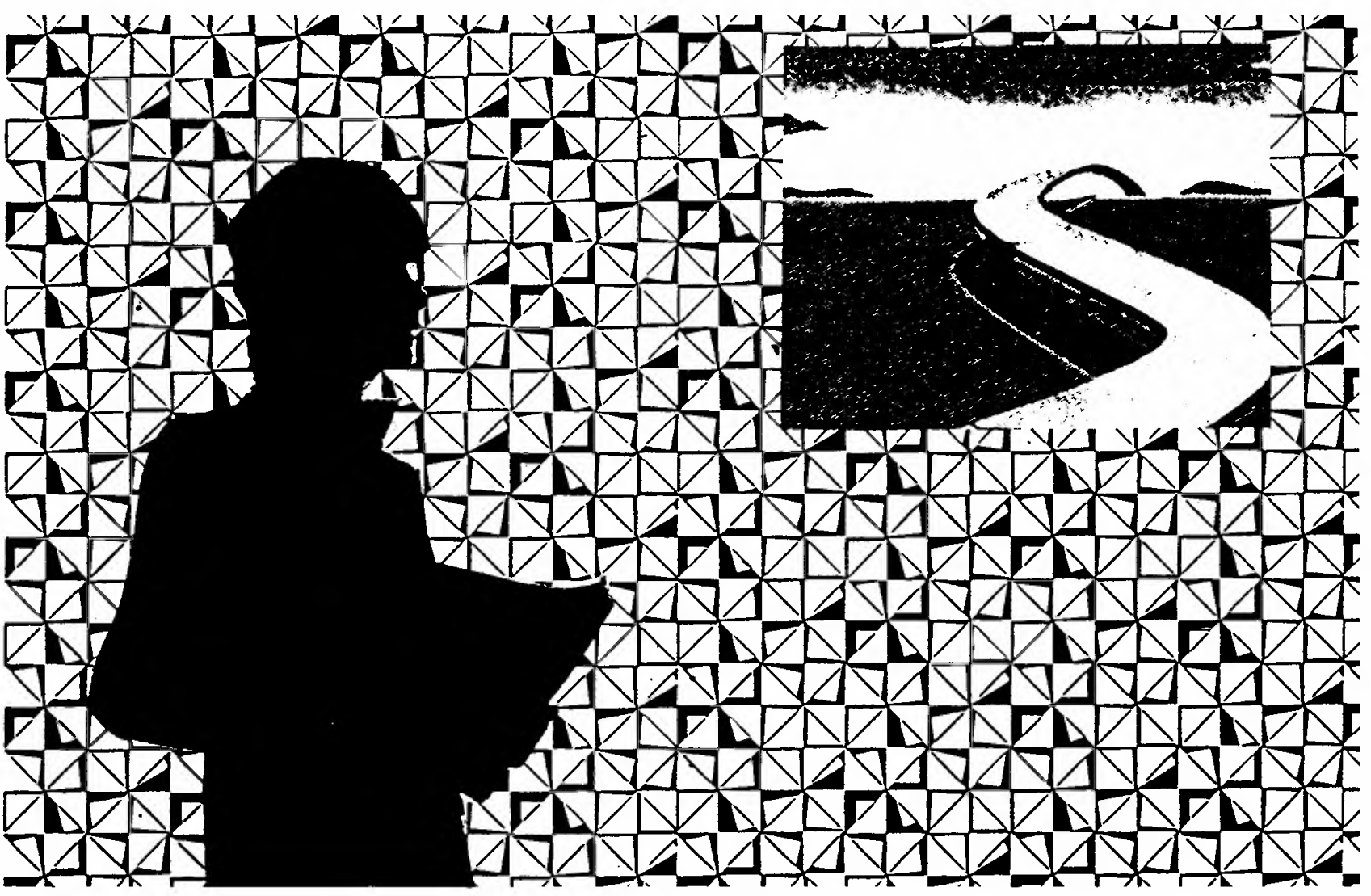

Maria Irene Stocco Betiol

Maria José Tonelli

Professoras de Psicologia do Departamento de Fundamentos Sociais e Jurídicos da Administração da EAESP/FGV.

* RESUMO: Este artigo analisa o desempenho da mulher executiva, assalariada, no trabalho.O estudo contesta algumas idéias sobre a atuação feminina, como, por exemplo, a de que a mulher corre menos riscos do que o homem nos negócios. Aponta para o fato de que o "sucesso" não é uma demanda social para a mulher, assim como ele o é para o homem. Buscam-se, também, as razões da discriminação da mão-de-obra feminina de alto nível, por parte das modernas organizações. Levanta a questão do desempenho da mulher no atendimento da dupla demanda, isto é, administração do lar versus administração de negócios.
* PALAVRAS-CHAVE: Desempenho de papéis da mulher executiva, discriminação da mulher nas organizações, imagem e sucesso profissional da administradora.

* ABSTRACT: This paper analyses the performance of the executive, waged, woman in organizations. This study objects some ideas about female performance in organizations, for exemple, they take less risks than men in business. It points out to the fact that "success" is not a social demand for women as it is for men.

It searches the reason of discrimination from modern organizations against woman's working in high levels. Analyses the way to face the double requirement in woman's life, that is, management at home and in the organization.

* KEY WORDS: The role-playing of the executive woman, discrimination against women in organizations, 


\section{INTRODUÇÃO}

0 cotidiano do trabalho em uma escola de administração de empresas mostrou, ao lado da literatura sobre mulher, mudanças ocorridas no desempenho do papel da mulher no mundo do trabalho.

Existe há muito tempo uma preocupação com o trabalho extra-domiciliar da mulher, em especial da trabalhadora de baixa renda. Esta faixa tem sido "privilegiada" pelas pesquisas, abrangendo temáticas variadas: vivências, conflitos, discriminação etc.

A leitura da Bibliografia Anotada 2, Mulher

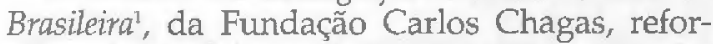
çou o desejo de pesquisar especificamente o desempenho da mulher em postos de comando.

Bruschini ${ }^{2}$ comenta que existem condiçōes facilitadoras para o desempenho profissional das mulheres das camadas média e superior da população. Uma delas é a presença de infra-estrutura doméstica, suporte para que a mulher possa exercer, com custos pessoais menores, atividades no domínio público. Outra condição se traduz pelo nível cultural, fator que parece permitir disputas em condições de igualdade, no mercado de trabalho.

Segundo referências do Serviço de Estatística de Educação e Cultura do MEC, na década de 70 , houve uma duplicação percentual das mulheres matriculadas no ensino superior, na área de ciências econômicas e administração de empresas. ${ }^{3}$

Na Escola de Administração de Empresas 1. FUNDAÇAO CARLOS Bibliografia Anotada 2. São Paulo, Brasiliense, 1981.

2. BRUSCHINI, M.C. Aranha. "Mulher e Trabalho: uma avaliacāo da década da mu Iher (1975-1985)". Revista da Fundacão Seade/São Paulo em Perspectiva, $2(\dagger)$ jan/abr 1986.

3. BARROSO Carmen Lúcia de Melo \& MELLO, Guiomar Namo de. "O acesso da muther ao ensino supelior brasileiro". Cadernos de Pesquisa, (15):56-7, dez. 1975.

4. O GVPEC é um programa da Escola de Administração de Empresas de Sāo Paúlo, da Fundacão Getúlio Vargas (EAESP/FGV), composto de um conjunto de cursos planejados para adaptaçāo e aperfeicoamento de executivos, conduzido pelo corpo docente da EAESP, que visa a ampliar o conhecimento dos processos administrativos e estimular a produçāo de novas idéias, para profissionais de diversas áreas. vo dos anos compreendidos entre 1985 e 1989

Tabela 1: Alunos matriculados na EAESP obteve-se o total de 430 homens inscritos contra o total de 96 mulheres.

A distribuição, em porcentagem, desses números está ilustrada na tabela 2.

$O$ fato de que tem havido um aumento significativo do número de mulheres nesses programas é indicativo de que as mulheres estão assumindo postos de comando e de que as empresas estāo investindo nas mesmas, já que, em geral, são as empresas que pagam esses cursos para seus funcionários.

Parece, não obstante, que as mulheres ainda estão em desvantagem no que se refere a esse tipo de investimento para formação. Para o total de 430 homens inscritos nos cursos e períodos supra citados, $76,2 \%$ foram financiados por suas respectivas empresas, contra o total de 96 mulheres inscritas e $62,5 \%$ financiadas.

Esse dado pode ser interpretado de duas maneiras: de um lado, as empresas investem menos em mulheres e mais em homens; de outro, se as mulheres não recebem apoio institucional, elas buscam superar estas lacunas investindo elas mesmas em sua formação profissional.

A amostra foi selecionada entre os alunos dos dois programas já citados (CIA e RH), além do curso de Marketing para Executivos, todos eles cursando o primeiro semestre letivo de 1989. Esses cursos foram escolhidos para coleta de dados por serem representativos para o campo da administração.

Após manuseio das fichas de inscrição de todos os alunos daquele semestre, optou-se pela escolha daqueles que pareceram mais adequados para a amostra em função da posição que ocupavam nas respectivas empresas, relaçōes de proximidade com a direção e/ou faixa salarial, quando havia este dado. Outro dado importante foi o estado civil; optou-se por homens e mulheres, solteiros e casados, com idades variando de 25 a 36 anos. A razão da inclusão de homens na amostra deveu-se ao fato de constar da temática a avaliação que o executivo faz do elemento feminino que ocupa a mesma posição que ele. Quanto à existência ou não de filhos, apesar de ser um dado significativo para o nosso trabalho, não foi possível uma seleção prévia, pois este dado não constava da ficha de

\begin{tabular}{|c|c|c|c|c|c|}
\hline SEXO & $1955 / 59$ & $1960 / 69$ & $1970 / 79$ & $1980 / 89$ & TOTAL \\
\hline$F$ & 001 & 0104 & 0811 & 1023 & 1939 \\
\hline$M$ & 212 & 1329 & 3242 & 2809 & 7592 \\
\hline TOTAL & 213 & 1433 & 4053 & 3832 & 9531 \\
\hline
\end{tabular}


Tabela 2: Distribuição anual de mulheres e homens inscritos no GVPEC (em\%)

\begin{tabular}{|c|c|c|c|c|c|}
\hline SEXO & $1^{\text {osem. }} 1985$ & $1^{1}$ sem. 1986 & $1^{1}$ sem.1987 & $1^{1}$ sem.1988 & 1'sem.1989 \\
\hline $\mathrm{F}$ & 6,86 & 12,05 & 17,05 & 24,00 & 31,03 \\
\hline M & 93,14 & 87,95 & 82,95 & 76,00 & 68,97 \\
\hline
\end{tabular}

inscrição; ocasionalmente, verificou-se que um homem entrevistado tinha um filho e nenhuma das mulheres entrevistadas tinha filhos.

Do questionário semidiretivo norteador das entrevistas, num total de 137 questões, foi dado destaque nas análises àquelas questôes que, próxima ou remotamente, tentavam responder às indagações que surgiram no "panorama teórico"

Essas entrevistas foram gravadas com a aquiescência dos entrevistados e realizadas nas dependências da própria instituição (EAESP/FGV).

Durante o processo de análise de onze entrevistas em profundidade (cada entrevista gravada teve, em média, duas horas de duração), percebeu-se que a amostra tinha três categorias de profissionais: assalariados, herdeiros e empreendedores. Estas informações não constavam das fichas de inscrição mas constituem-se importantes diferenciadores para a focalização de questões e ideologia na avaliação de pares ou subordinados. Optou-se pela apresentação, neste artigo, das respostas dos entrevistados assalariados, em número de seis.

Apesar de o questionário ser unificado, percebeu-se, ao longo das análises, que cada entrevista estava marcada por um "tom", ressaltando as peculiaridades dos entrevistados, que variaram dos mais entusiastas aos mais depressivos.

Este trabalho é a resultante da interpretação do conteúdo das entrevistas; como pesquisa exploratória, trabalhou-se com as percepções dos entrevistados. O pressuposto é o de que estas formas de perceber a organização são fatores determinantes das relaçōes que os sujeitos estabelecem com as organizações.

Este estudo é uma tentativa de problematizar a inserção da mulher nas organizações e levantar questões pertinentes à atuação da mesma em postos de comando de nível médio, independentemente de suas origens sócio-econômicas; verificar a repercussão do trabalho da mulher e a possibilidade de vivência do feminino nas organizaçōes sob a ótica de homens e mulheres em postos de comando; analisar questões apontadas na bibliografia, tais como: medo do sucesso e tomada de riscos e sua consonância com dados da realidade pesquisada.

\section{PANORAMA TEÓRICO DE ESTUDOS CONCERNENTES AO TEMA}

A atividade feminina na força de trabalho brasileira vem crescendo segundo os dados dos censos demográficos de 1970 e 1980. Bruschini apresenta alguns motivos para explicar esse aumento:

"... a aceleração do processo de desenvolvimento econômico expande o mercado de trabalho em geral, provocando também maior demanda por mão-deobra feminina. De outra parte, a mudança nos valores relativos ao trabalho feminino e à difusão de novos padrões de comportamento facilita a oferta de trabalhadoras. A queda na fecundidade da brasileira e a ampliação de seus níveis de escolaridade atuam também na determinaçāo deste movimento. Mas, o ingresso das mulheres no mercado de trabatho também é explicado pela queda do nivel de renda real de grande parte da populaçāo brasileira na última década." 5

Existe, ainda segundo Bruschini, citando dados da Fundação I.B.G.E., correlação entre anos de estudo da mulher trabalhadora e nível de inserção no mercado de trabalho. No estado de São Paulo, por exemplo, os índices são os seguintes: para nove anos ou mais de estudo, a inserção é de $60,3 \%$ e para mulheres sem instrução ou com menos de um ano de instruçāo, 23,8\%. ${ }^{\circ}$

As mulheres que têm maior nível de escolaridade poderiam, segundo a autora, estar apresentando essa correlação porque, primeiro, a maior escolaridade implica em maiores possibilidades de participação pela própria configuração do mercado; segundo, porque maior escolaridade está associada com menor número de filhos e maiores possibilidades de infra-estrutura de apoio; finalmente, terceiro, porque maior escolaridade traz possibilidades de trabalhos mais gratificante. Apesar dessa abertura de mercado para mulheres com maior escolaridade, a autora conclui que se verifica a continuidade da discriminação, porque raramente as mulheres chegam a postos de comando.

Analisando as condições de trabalho da mulher universitária, Blay diz que:

"As universitárias atuam principalmente nos setores administrativos ou em serviços de assistência e saúde. Não sāo aproveitadas nos setores de
5. BRUSCHINI, M. C. Op. cit., $p .43$

6. Idem, ibidem, tabela 5 , p.44. 
7. BLAY, Eva. "Trabalho industrial $X$ Trabalho Doméstico - A ideologia do trabalho feminino". Cadernos de Pesquisa, (15), dez. 1975, p.9.

8. Idem, ibidem, p.13.

9. BRUSCHINI, M.C. Aranha. "Mulher e trabalho: engenheiras, enfermeiras e professoras". Cadernos de Pesquisa, (27), dez. 1978, p.10.

10. Idem, ibidem, p.17.

11. Ver: DEJOURS, Christophe. A loucura do trabaIho. Estudo de Psicopatologia do Trabalho. $2^{\mathrm{a}}$ ed. São Paulo Cortez Editora, 1987; e PITTA, Ana Maria Fernandes. Hospital, dor e morte como ofício. São Paulo, Hucitec, 1990.

12. BARROSO, Carmem Lúcia de Melo \& MELLO, Guiomar Namo de. Op. cit.

13. BARDWICK, Judith \& DOUVAN, Elisabeth. "Ambivalence: socialization of human". In: GORNIK, Vivian \& MORAN, Barbara K. (orgs.) Human in sexist, New York, Signet, 1971, pp.147-59.

14. BARROSO, Carmem Lúcia de Melo \& MELLO, Guiomar Namo de. Op. cit.; e BRUSCHINI, M.C.A. "Mulher e Trabalho: engenheiras, enfermeiras e professoras". $0 p$. cit.

15. HORNER, Matina. Sex Differences in achievement motivation and performance in competitive and noncompetitive situations. University Microfilms, Michigan, 1968 . produção, mesmo quando muito bem preparadas para isso"...

"...assim, a mulher universitária que trabalha na indústria... não ocupa cargo de direção ou gerência".?

Segundo a autora, o papel da mulher, na época de sua pesquisa (1975), era questionado pela sociedade, sendo que estudo e trabalho representavam formas inovadoras em relação ao "verdadeiro" papel da mulher, ou seja, o de esposa, mãe e dona-de-casa.

A autora constata que as entrevistadas mostravam atitudes mais favoráveis ao início da atividade profissional da mulher do que os homens entrevistados. $O$ casamento, porém, e a presença de filhos, sobretudo quando menores, eram fatores que impulsionavam a mulher a aceitar o afastamento e mesmo o abandono do trabalho extra-domiciliar.

Segundo a autora, "a trabalhadora não consegue libertar-se do modelo ideal de mulher doméstica, ideologicamente valorizada, e propor como alternativa novos comportamentos sociais ligados ao trabalho."

Os dados apresentados na introdução deste trabalho mostram uma evolução dessas condições.

A pesquisa de Bruschini parte da hipótese que mulheres com distintas formações universitárias teriam diferentes concepções sobre o trabalho e o papel que este assume em sua vida.

A suposição era de que as mulheres que haviam seguido carreiras consideradas próprias para o sexo masculino teriam um comportamento fora dos padrões convencionais, vencendo preconceitos e sanções sociais. Ao estudar uma população constituída por engenheiras, enfermeiras e professoras, a pesquisa informa que estes grupos profissionais são diferentes e têm atitudes e comportamentos diferentes. Ao contrário do que se poderia supor, é no grupo de engenheiras que se encontra o maior contingente de mulheres casadas e com filhos.

A autora conclui que:

"Parece que o fato de se dedicar a uma profissão masculina não relegou estas mulheres a uma posição de não realização de seus papéis femininos de esposa e mãe, pelo menos em comparação com as outras profissionais."

Por outro lado, na enfermagem, profissão tipicamente feminina, encontra-se a maior porcentagem de mulheres solteiras e sem filhos. Segundo a pesquisa, tanto engenheiras quanto enfermeiras se interessam pela carreira e este entusiasmo das engenheiras pela profissão mostra "... que o afastamento da mulher de uma carreira tipicamente masculina, como é o caso da Engenharia, sob a alegação de que ela teria maior dificuldade em constituir familia e em se dedicar a ela, não passa de um mito."10

A partir de pesquisas mais recentes sobre custo psíquico do trabalho ${ }^{11}$, podemos levantar a hipótese que a profissão de enfermagem exaure a profissional, não the restando energia para investir em vida doméstica e filhos, cuja demanda emocional é igualmente forte para a mulher.

A autora sugere que expectativas familiares podem ter influenciado a escolha de carreira e que, portanto, seria desejável um aprofundamento sobre este tema.

Barroso e Mello $^{12}$ desenvolveram ampla pesquisa sobre o "acesso da mulher ao ensino superior brasileiro", onde apontam, com profundidade, questões da mulher no ensino superior e seu desempenho nos exames vestibulares. Não obstante o desempenho feminino ser positivo e crescente durante o período escolar, se comparado ao desempenho masculino, no momento da realização de concursos e exames de ingresso, as mulheres têm desempenho desfavorável.

As autoras sugerem que as mulheres enfrentam uma situação de ambivalência frente à realização profissional, ou seja, elas se confrontam com o medo do sucesso. Parece que sucesso profissional pressupõe uma incompatibilidade com relacionamento afetivo e maternidade. Citando Bardwick, as autoras concordam com sua afirmação de que "o conflito feminino entre ser competente e ser amada está por trás da ambivalência em relação ao trabalho fora do lar."13

Prosseguindo, dizem que os estereótipos acerca da competência e das inclinações da mulher parecem ter papel importante tanto na avaliação que ela faz de si mesma, como nas avaliações de outros.

As pesquisas de Barroso e Mello e Bruschini $^{14}$ trazem dados que, aparentemente, não são convergentes. De um lado, Bruschini aponta como um mito a incompatibilidade entre papel materno na família e o exercício profissional da mulher. Por outro, Barroso e Mello, citando diversos autores, apontam o conflito existente entre ser uma profissional competente e estabelecer relações afetivas estáveis e maternidade. Essa aparente divergência parece-nos ser devida à diversidade de contexto sócio-econômico-cultural das duas pesquisas.

Horner $^{15}$, em seus estudos com mulheres universitárias americanas, chega aos seguintes resultados: mais de $65 \%$ de mulheres universitárias entrevistadas associam a realização da mulher, em atividades socialmente 
consideradas masculinas, com ansiedade, culpa e conseqüências negativas do sucesso (perda da feminilidade, rejeição social).

Comparativamente, homens universitários deram menos de $10 \%$ de respostas negativas à realização profissional masculina. Essa pesquisa deu origem à expressão "medo do sucesso", cunhada por Horner. Como conseqüência, o desempenho feminino em situações competitivas parece ser pior do que em situações não-competitivas.

Monahan, Kuhn e Shaver ${ }^{16}$ fazem uma réplica ao trabalho de Horner ao sentirem dificuldade de concluir se os resultados obtidos por Horner são devidos à dinâmica intrapsíquica dos sujeitos ou a estereótipos culturais.

Ampliando os estudos, os autores concordam com um dos resultados de Horner, que o sucesso da mulher em campos tradicionalmente masculinos envolve considerável negatividade e conflito. Por outro lado, parece que ambos os sexos não vêem impedimentos para o sucesso masculino.

Como nessa réplica as respostas negativas são dadas por ambos os sexos em relação ao sucesso feminino, isto reforça a idéia de uma variável cultural na determinação das avaliações.

Os autores, citando estudos recentes de Katz (Universidade de Stanford, sem data), indicam que o sucesso das mulheres, na visão das próprias mulheres, em campos tradicionalmente femininos é bem visto.

Concordando com a psicanálise, Horner afirma que as crenças são adquiridas na infância e resistentes à mudança. Monaham, Kuhn e Shaver, todavia, indicam que as respostas negativas das mulheres diminuíram com o aumento da idade, o que permite supor mudança de atitude. Os autores colocam, também, a defasagem do tempo entre as duas pesquisas como um fator a ser considerado; houve neste período, 1970/74, uma crescente atenção ao movimento feminista, reforçando, talvez, a idéia de que o medo do sucesso é cultural.

Tecendo considerações sobre a psicanálise e o feminismo, Ferreira retoma os trabalhos de Freud e cita várias passagens em que ele, Freud, diz se sentir com dificuldade de saber qual o desejo da mulher. Em uma das citações extraídas de Ernest Jones e colocada pelo autor, Freud diz:

"A grande pergunta nunca respondida, e que eu proprio nunca fui capaz de responder, apesar de meus trinta anos de pesquisa da alma feminina, é: O que a mulher quer?"17

Ferreira prossegue com a seguinte questão:

"Será legitimo atribuir a Freud a intuição de que, pelo discurso da razão 'masculina', o homem continuará desconhecendo a mulher?"18

Segundo Ferreira, fica claro que a Psicanálise abriu caminhos sobre a questão da mulher, sobretudo quando destaca o problema da sexualidade reprimida e censurada ao longo dos anos, porém não elucida a conflitiva mãe-mulher.

O autor prossegue:

"A ordem social, política e religiosa opta pela mãe e, a todo custo, a preserva, na escola, em casa, na cidade e na pátria. Essa produção é uma produção masculina, cujo resultado é muito mãe e pouco mulher."19

Madel Luz ${ }^{20}$ discorre sobre a existência de uma crise nas representações sociais sobre masculino e feminino; enquanto participante de alguns debates sobre a questão feminina, constata a existência de certa ansiedade, comum a homens e mulheres. Essa ansiedade diz respeito à perda de pontos de referência tradicionais sobre o que é ser homem ou ser mulher hoje. Os pontos de referência tradicionais se perderam sem que novos pactos nas relações homem-mulher tenham ocorrido.

A hierarquização de papéis estruturada durante o século XIX entre homem e mulher encaminhou-se para uma divisão política entre domínio público e domínio privado.

"... com a atribuição ao homem do controle 'público' (participação nas decisões da sociedade política, na gestão da cultura e do trabalho), e, à mulher, do controle do 'privado' (gestão do lar, manipulação do corpo e da mente da prole através da educação, manipulação do afeto do marido)" . ${ }^{21}$

A autora prossegue dizendo que, em todo esse processo de construção social, com essa divisão de papéis, surgiu um conjunto de representações sociais sobre masculino e feminino e lhe foi atribuído o caráter de "estrutura natural".22

As contestações que se sucedem a esse modelo e as resistências à mudança vêm gerando um clima passional e uma certa perplexidade, principalmente do público masculino, gerando uma crise nas representações, com a incapacidade de se criarem novas formas de relação.

As mulheres têm sido, através dos movimentos que têm criado, "o elemento detonador da crise... uma vez que sobre elas é que recai o ônus maior do pacto anterior". ${ }^{23}$

Prossegue a autora:

"a entrada das mulheres na produção, sobretudo a partir da Segunda Guerra Mundial (das mulheres de estratos médios urbanos, diga-se de passagem, uma vez que as mulheres operárias ai estão desde o século XIX, mesmo no Brasil), é um condicionamento apreciável, na medida em que cria o fenômeno da dupla jornada de trabalho da mulher,
16. MONAHAN, L.; KUHN, D. \& SHAVER, P. "Intrapsychic versus cultural explanations of the 'fear of succes' motive". Journal of Pesonality and social Psychology, 29(1), 1974.

17. FERREIRA, João Batista. "Freud e o Feminismo: consideraçōes". In: DA POIAN, C. (org.) Homem - mulher abordagens sociais e psicanalíticas. Rio de Janeiro, Liv. Taurus Ed., 1987, p.52.

18. Idem, ibidem, idem.

19. Idem, ibidem, p.58.

20. LUZ, Madel T. "Identidade masculina-feminino na sociedade urbana brasileira atual: crise nas representacões". In: DA POIAN, C. (org.). Op. cit.

21. Idem, ibidem, p.72.

22. Idem, ibidem, p.73.

23. Idem ibidem, p.79. 
elemento potencialmente implosivo das relações do casal." ${ }^{24}$

Além desse condicionamento forte, $o$ acesso ao direito de cidadania (voto, educação, direito de associação), os meios de comunicação, a contracepção etc. influenciam sobremaneira esse movimento em busca de auto-afirmação. Há uma exigência crescente do partilhamento do ônus da família, da presença afetiva do parceiro. Ao lado das antigas representações patriarcais existe agora a expectativa de novos comportamentos femininos. Surge a necessidade de melhor desempenho nas sociedades industriais e aumenta a competição que leva a mulher a se sentir "sobrecarregada de papéis", sem nenhuma compensação, ao nível pessoal, afetivo. ${ }^{25}$

Se existem alguns homens de vanguarda que compartilham mais o ônus do lar e dos filhos e aplaudem o sucesso das mulheres, existe também a permanência de antigas representações do masculino e feminino para muitas mulheres.

A mudança nas representações está ameaçada, segundo a autora, pela educação dada aos filhos dentro do lar, reproduzindo os papéis do antigo pacto.

"Meninas estudam balé; meninos, judô. Meninos são agressivos, meninas meigas e delicadas. Meninas ajudam nas tarefas da casa, meninos jogam bola" ... "A superação do impasse atual não passa por modelos teóricos, mas pelas práticas novas que tanto homens como mulheres ousem enfrentar. ${ }^{26}$

E. Sulerot ${ }^{27}$ desenvolve amplo estudo sobre o trabalho feminino. Destaca-se desta leitura uma descrição que a autora faz do significado do trabalho para mulheres casadas de diferentes estratos sociais.

Assim, para as mulheres de baixa renda (operárias, camponesas) em que o trabalho é uma necessidade, instala-se um conflito entre a atividade a ser desempenhada para a sobrevivência e a imagem estereotipada da mulher que existe nos meios de comunicação: mulher é dona-de-casa. A autora discorre sobre alguns sentimentos característicos desse grupo: frustração e exclusão social pela comparação dessa mulher com a de outras classes sociais e dentro do seu próprio grupo, em relação aos homens, no pagamento por tarefas e pela acu24. Idem, ibidem, idem.

25. Idem, ibidem, p.84.

26. Idem, ibidem, pp.85-6.

27. SULEROT, Evelyne. Historia y Sociologia del Trabajo femenino. $2^{\mathrm{a}}$ ed. Barcelona, Ed. Península, 1988. do, para essas mulheres, há a sustentação dos grupos de pares: elas apreciam a camaradagem, o riso e a descontração com outras companheiras; há também intensa dedicação ao trabalho, numa corrida contra si mesma.

O segundo grupo, a classe média, tem uma visão diferente de suas funções. A primeira característica é que falam espontaneamente que o dinheiro de seu trabalho não é imprescindível. $O$ destino do dinheiro é dado a bens de consumo, melhor futuro para a família. Portanto, o fruto do trabalho extra-domiciliar não se destina à sobrevivência, mas ao incremento do bem-estar. Essas mulheres apresentam, segundo a autora, pouca ambição: estão satisfeitas com o mero fato de trabalhar. Elas são mais racionais em atividades caseiras, "se viram bem", em que pesem os horários dificultosos; são excelentes mães de família, trabalham pelos filhos.

A autora aponta ainda nesse grupo uma divisão, pois as mulheres cujas mães não trabalhavam têm a idéia de que farão por seus filhos ainda mais do que as mães fizeram por elas. Outra característica é a atitude ante a doença: parece que as mulheres desse grupo ficam menos doentes que as mulheres que ficam em casa.

O terceiro grupo visto pela autora é o de mulheres que exercem profissões que lhes agradam, ou seja, parecem se enquadrar em "através do meu trabalho, me realizo". Suas tarefas não têm fundamento econômico, é um grupo minoritário, com ambição e interesse extremados pelo que fazem. Parece que não se identificam com a imagem de mulher difundida na cultura de massa. Parecem ter apoio dos maridos, preocupação com os filhos, mas não se imaginam sem trabalhar.

A autora traz ainda idéias sobre as condições do trabalho feminino e a vida privada: há maior hostilidade nas relações entre mulheres e homens da classe operária, porque os homens já são tão explorados fora de casa que não querem perder o único lugar em que são os primeiros; além disso, a idéia de trabalhar fora vem acompanhada do temor de que haverá maior liberdade sexual, ficando as $\mathrm{mu}-$ lheres exageradamente independentes. $\mathrm{Na}$ classe média, a oposição entre os cônjuges aparece maior quando estes são entrevistados em separado. Além disso, a autora aponta que o significado do trabalho é diferente para homens e mulheres: para o homem, o trabalho é o inverso de liberdade, como então pensar que alguém que não precisa, queira trabalhar? Assim, o problema que as mulheres enfrentam ao trabalhar tem origem fora de seu local de trabalho. 
Outra autora, Tânia Salem ${ }^{28}$, analisa as relações entre pais e filhos adultos, nos extratos econômicos médios superiores. Ela procura compreender como estão se processando os novos papéis sexuais no domínio privado e no domínio público, isto é, quais papéis sofreram, verdadeiramente, modificações e quais papéis permaneceram cristalizados.

A autora mostra uma clara distinção do significado do trabalho para homens e mulheres. Para os homens, o trabalho é autocentrado, isto é, o homem define-o a partir de motivações pessoais. Para a mulher, a figura de "outros" é central na sua escolha, ou seja, marido e filhos são parte essencial de sua própria identidade.

Para os homens da geração mais velha estudados, o trabalho era o centro da vida e sua ausência tinha como significado a própria morte.

Para as mulheres da geração mais velha, $o$ trabalho fora do lar significava "uma tentativa de responder à crise de depressão, associada à falta de atividade, 'vazio'...", aliadas à "perda de função no lar ocasionada, basicamente, pelo crescimento dos filhos". ${ }^{29} \mathrm{Em}$ todos os depoimentos femininos desse grupo, as figuras dos filhos e/ou maridos estavam intrinsicamente vinculadas à definição do significado atribuído às atividades extra-domésticas. E também sempre houve uma associação entre atuação no âmbito extra-doméstico com a esfera doméstica: ideologia de abnegação e despojamento em prol dos outros. Outro aspecto valorizado por estas mulheres no trabalho extra-doméstico foi o contato com os outros, o meio de fazer ambiente social e novas amizades. Mais ain$\mathrm{da}$, a autora percebeu um sentimento de ilegitimidade na participação da mulher no mercado de trabalho: ou se trata de uma extensão de seu papel na família ou ela se percebe "brincando de trabalhar". Na discussão sobre filhos e o domínio público, a autora percebeu que a motivação para a escolha de carreira para alguns entrevistados se revestiu de pouca firmeza e amadurecimento e, para outros, a escolha parecia ser condizente com as próprias inclinações: o estudo é visto como uma preparação para o ingresso no mercado de trabalho. Para os pais, os estudos dos filhos são vistos como "iniciadores de uma nova tradição 'cultural' na familia."

A autora diz ainda:

"Em suma, utilizando a perspectiva proposta por Bourdieu, a situação financeira dos pais, aliada à instrução superior dos filhos, significa a duplicação, na ordem simbólica, do êxito econômico que os primeiros consolidaram no decorrer de suas vidas. O fruto desta união implica, como mostra o autor, num reforço do próprio poder. ${ }^{\prime \prime 1}$
Assim, para essa nova geração, o "prazer" está incluído na escolha profissional: hoje, o jovem opta por uma profissão que mais se identifica com ele.

Para as filhas, entretanto, as motivações não são intrínsecas, elas ainda têm determinantes externos. A autora observa ainda que nessa geração as mulheres não suportam enfrentar a concorrência e não são preparadas para disputa ou fracasso.

A formação universitária para a nova geração feminina tem mais uma função social do que de preparação pessoal com vistas à atividade profissional futura. A autora conclui que, neste contexto econômico, "as qualidades de 'moça prendada' dos extratos médios e superiores se deslocam das prendas domésticas para as prendas intelectuais ou culturais, e o diploma universitário se converte em um mecanismo que confere prestígio social a seus pais e maridos." ${ }^{32}$

A autora diz que "instala-se uma experiência de conflito, mais do que uma alteração efetiva na forma de conceber o papel tradicionalmente confinado à mulher (...) As moças estão submetidas a uma socialização que está revestida de um cunho mais ambivalente. ${ }^{33}$

Assim, para as mulheres da geração mais velha, o trabalho é uma forma de se doar, uma extensão de seu papel na família; e para as filhas, o trabalho é uma tentativa de romper com os pais, num esforço de reavaliar seu papel na família, ou seja, um conflito que se estabelece entre ser uma pessoa destinada a responder às demandas de "outros" e de outro lado buscar uma identidade e um perfil mais próprios.

Castro ${ }^{34}$, ao tentar traçar "o perfil da mulher empresária chilena", tem um objetivo claro: determinar as características que regem o comportamento profissional da mulher empresária. A hipótese, ponto de partida da investigação, é de que não existem condições de mercado que favoreçam as mulheres empresárias, por isso seu desempenho está dado por condições situacionais e de personalidade. Para a realização do estudo, a autora selecionou a nível de mercado as seguintes variáveis: acesso ao capital, discriminação sexual no plano de trabalho, aspectos legais e preferência para desenvolver determinados setores econômicos. As variáveis situacionais foram: herança, estado civil, condições econômicas, educação e relações públicas. Com relação às condições econômicas, a autora apresenta uma diferenciação importante: para as classes baixas, $o$ trabalho tem o sentido imediato de garantir a sobrevivência. Para as classes média e alta, o trabalho tem o caráter de desafio. Quanto à variável personalidade, a autora levantou al-
28. SALEM, Tânia. $O$ velho $e$ o novo: um estudo de papéis e conflitos familiares. Petrópolis, Vozes, 1980.

29. Idem, ibidem, pp.61-2.

30. Idem, Ibidem, pp.77 e 79.

31. Idem, ibidem, p.82.

32. Idem, ibidem, p.114.

33. Idem, ibidem, p.115.

34. CASTRO, Tercila Moreno. "Perfil de La Muyer Empresaria Chilena". Economia y Administración, (34), jun. 1988. 
guns traços qualitativos: propensão frente ao risco, espírito empreendedor, criatividade, espírito independente, liderança, personalidade metódica, confiança e segurança em si mesma, ambição, intuitividade versus racionalidade, perseverança e competitividade.

As conclusões que a autora retratou foram as seguintes: não há, no Chile, discriminação no plano legal e houve uma evolução na porcentagem da força de trabalho feminino. Há uma tendência de se incrementar esta relação com uma concentração maior de mulheres na área do comércio. Dentre as variáveis situacionais, a autora conclui que o estado civil, na amostra estudada, não é um fator determinante da atuação profissional, sendo que o nível educacional é uma condição necessária mas não suficiente para o desempenho. Com relação às variáveis de personalidade, a autora demonstrou que uma característica especial da mulher empresária é sua posição frente ao risco: elas preferem crescimento lento a se lançar em atividades de risco. Assim a criatividade demonstrada também é baixa, implicando em não correr risco. Elas também não participam de negócios que exijam alta inovação. No que concerne ao item espírito independente, obteve-se que a mulher tem um estilo mais centralizado, custa a delegar e quando o faz, controla rigidamente. São líderes formais e respeitadas pelos empregados. Sobre o item intuitividade versus racionalidade, a autora mostrou que as mulheres tendem a seguir processos racionais, por aversão ao perigo, seguindo estudos e orientações. São perseverantes e firmes. De acordo com a autora, as mulheres nos negócios tentam vencer por suas próprias condições ao invés de atacar o competidor.

Oliveira $^{35}$, ao discutir o futuro do movimento feminista, diz que as mulheres, quando deram o grito de "igualdade, não sabiam até que ponto estavam engatilhando uma armadilha para si proprias". Segundo a autora, a psicologia americana define o adulto com atributos do mundo masculino: autonomia, agressividade, racionalidade. A mulher normal é definida com atributos do mundo infantil: dependência, emotividade e inconstância. A autora coloca que a mulher atual enfrenta um paradoxo: ou é mulher ou é adulta.

Em nome do "moderno" (industrialização, urbanização) e da igualdade, a mulher mudou: é metalúrgica, advogada e executiva, mas como mudar realmente, se o outro não mudou? Mudar o exercício do papel feminino implica em mudar o papel masculino, mas isso não parece ter acontecido. Sendo assim, a autora conclui que realmente a mulher não mudou e tem que enfrentar uma "... mensagem dupla e contraditória: para ser respeitada, seja universal (pense, aja e trabalhe como homem); mas, para ser amada, continue sendo mulher. Seja homem e seja mulher". ${ }^{36}$

\section{CONSIDERACÕES GERAIS SOBRE AS ENTREVISTAS ${ }^{37}$}

\section{Significado do trabalho, origem social e suporte familiar}

$\mathrm{Na}$ comparação entre as análises das entrevistas, a primeira diferença que aparece de forma nítida é a do significado do trabalho.

Para os entrevistados, homens e mulheres de origem sócio-econômica mais baixa, o sentido é "sobrevivência". Para as mulheres de nível sócio-econômico mais alto, o significado é "independência e auto-realização". Para os homens desse mesmo extrato social, é "manutenção do poder conquistado". Nesta amostra, as motivações para o trabalho ainda estão vinculadas às origens sócio-econômicas, não obstante os postos de maior status social ocupados atualmente.

Homens e mulheres do extrato sócio-econômico alto se reconhecem como pares e com os mesmos desejos e aspirações, identificando igualmente a "sobrevivência" como fator que mobiliza a ação dos extratos mais baixos. Provavelmente essa percepção se deva à postura que os executivos de origem mais modesta têm diante de seus pares de origem econômica mais alta.

A imagem que um entrevistado tem da mulher executiva de nível econômico alto é que ela "está numa fase de crescimento, está se desenvolvendo ainda (....) ela não trabalha por sobrevivência, mas para chegar num nível mais elevado". Portanto, mesmo respeitando a competência e reconhecendo a mulher de mesmo nível econômico como tendo direito às mesmas motivações para o trabalho, fica claro para o homem que a mulher ainda tem que fazer um esforço, pois o seu lugar na organização não está garantido.

As mulheres percebem o trabalho do homem como um papel prescrito: "para o homem é uma obrigação social da qual não há possibilidade de opção; tem aquele ranço machista, já nasce com o objetivo de trabalhar; é o homem da casa, tem que se sustentar e dar continuidade à familia. Já nasce intrínseco nele, independe da familia e da classe social".

O suporte econômico da família de origem permite às mulheres expressarem com clareza o desejo de sucesso sócio-profissional. Esse desejo não aparece para as entrevistadas dos níveis sócio-econômicos médio-baixos. Se o coletivo familiar é carente, o espaço do desejo 
de cada um fica mais restrito. Nesta condição, quando há o espaço de exteriorização do desejo, prepondera o desejo masculino. Já a mulher de nível médio-alto pode lutar pela autorealização, pois há a possibilidade de aceitação por parte do homem. Há um compartilhamento desse desejo, há um estímulo para a realização feminina e o homem cede nas exigências domésticas. $O$ homem deixa de ser um dominador para ser um "incentivador" do sucesso feminino. Nota-se uma mudança de expectativa do homem sobre o comportamento da mulher enquanto esposa. Na pesquisa de Salem ${ }^{38}$, para as camadas sócio-econômicas média-altas, havia uma exigência de diploma universitário como um predicado da mulher esposa, mas não havia a expectativa de desempenho profissional ou mesmo de sucesso. Parece haver hoje um incentivo do marido para o sucesso da mulher, se ela exteriorizar o desejo; não há, porém, forte exigência social para o sucesso.

Nota-se que o incentivo do marido para o sucesso profissional permanece o mesmo. Se antes o diploma universitário por si só já era satisfatório como "predicado" da esposa, hoje o "sucesso profissional" parece ser o predicado desejável. O apoio à carreira da esposa, onde o homem cede nas exigências domésticas, pode ser uma troca vantajosa e mesmo justa, na medida em que o sucesso profissional feminino repercutirá positivamente no prestígio social do marido, mesmo que a ausência da mulher gere alguns transtornos no coletivo doméstico.

A maioria das entrevistadas relataram que suas mães não estavam satisfeitas com seus papéis de donas-de-casa e estimularam fortemente a mudança de papel para as filhas. As sonhadoras do passado mobilizaram as inovadoras da atual geração de executivas. Segundo uma entrevistada "o sentido de libertação feminina foi pego pela minha mãe, que instituiu tal projeto como um bebê seu (...) tudo o que sou hoje devo à minha mãe".

Os estilos de família de origem dos entrevistados são bem diferenciados, gerando uma avaliação do significado e da inserção no mercado de trabalho de forma também diferenciada.

O relacionamento homem-mulher, de forma complementar e construtiva, pode estar presente no histórico familiar das pessoas de sucesso. O suporte de positividade pode vir de ambos os pais ou de um deles.

No caso de uma das entrevistadas, sua mãe sempre "exigiu" igualdade de tratamento para ela e para o irmão; de uma certa forma enfrentou o marido, que era mais tradicional na forma de criar filhos. Apesar da diferença no trato de filhos homens e mulheres por parte do pai dessa entrevistada, a mesma reconhece que ambos são muito positivos, protetores $\mathrm{e}$ flexíveis, para mudarem de opinião naquilo que for o melhor para os filhos.

Uma família de origem, cuja dinâmica entre pai e mãe é conflitiva, parece ter predisposto um entrevistado a uma forma mais depressiva de enfrentamento do trabalho. Um modelo mais harmônico e ameno sem grandes exigências parece ter gerado em outro entrevistado uma acomodação e pouca disponibilidade de luta. Por outro lado, um modelo mais ambicioso e exigente, mas com equilíbrio, parece ter impulsionado para o sucesso e a mudança. Uma família mais tradicional, não só abriu portas como enfatizou a necessidade da manutenção do poder. Uma família mais rígida, de pouca expressão de afeto, parece ter gerado em nosso entrevistado um fechamento para relações de trabalho.

A intenção não é generalizar essas considerações para o universo dos executivos, mas não é possível deixar de assinalar a relação percebida entre as configurações das famílias de origem e as posturas atuais dos entrevistados enquanto executivos.

\section{Imagem e discriminação da mulher execu- tiva no trabalho}

Há uma geração de mulheres na sociedade brasileira que ainda luta pelo reconhecimento. $\mathrm{Na}$ administração de negócios, as mulheres que se sobressaem ainda são objeto de notícias, de pesquisas, citações em revistas e jornais, o que prova que isto é incomum e chama a atenção da sociedade.

Numa rápida apreciação de reportagens de revistas e jornais destacaram-se duas características:

a) muitas dessas mulheres atuam em áreas que dizem respeito ao universo feminino, tais como: moda, roupas infantis, cosméticos, alimentação etc.;

b) são empreendedoras, isto é, donas de seus negócios e não têm, portanto, que enfrentar a competição direta com o homem por determinados postos nas organizações.

Para as mulheres que entram nas organizações, o caminho não está aberto; o investimento psíquico que elas têm que fazer parece ser maior do que o investimento das empreendedoras e maior do que o da maioria dos homens buscando o mesmo cargo.

\section{Riscos e erros}

A imagem que alguns entrevistados do se- 
39. CASTRO, T. M. Op. cit. Vale ressaltar que o trabalho desse autor focaliza mulheres chilenas, empresárias e não assalariadas, 0 que talvez explique a diferença de atitude frente ao risco.

40. Parece-nos que esta avaliação dos entrevistados de que o uso da sexualidade nas organizações é prerrogativa das camadas de menor poder de influência, é uma defesa psicológica que transparece como estereótipo social. Sievers faz menção de um mecanismo projetivo inconsciente, utilizado pelos executivos dentro das organizações, que consiste em atribuir os aspectos inadequados das condutas humanas aos escalões inferiores da hierarquia, resguardando, para os escalões superiores, os aspectos positivos, idealizados. SIEVERS, Burkard. "Além do sucedâneo da motivação". Revista de Administracão de Empresas, Sāo Paulo, 30(1), jan./mar.1990.

41. De acordo com Kernberg. "(...) um pouco de erotização dos relacionamentos de trabalho pode ser um incremento para 0 grupo de trabalho (...) mas quando as pressões regressivas levam à transposição das fronteiras sexuais estas conduzem a uma liberação dos componentes agressivos (...) com o rompimento geral das relações interpessoais no sistema." KERNBERG, Otto. Mundo Interior e Realidade Exterior. Rio de Janeiro, Imago, 1989, p.223. xo masculino têm da mulher executiva é que esta não tem tantas possibilidades de erro quanto o homem, isto é, se ela errar, além do erro "ainda é mulher e o tombo é maior". Dessa forma, a mulher teria que se assegurar de suas idéias e projetos para correr menos riscos do que o homem.

Um entrevistado avalia a ação administrativa da mulher como mais cautelosa dizendo que "ela ainda não pode errar (...) seria mais desgastante para ela se errasse (...) o poder ainda é uma característica masculina e a mulher, para ser um bom profissional, tem que ser um homem". Porém, todos os entrevistados do sexo masculino, ao serem indagados sobre os riscos que correm, afirmaram que eles próprios não correm riscos na organização; portanto, a imagem que os homens têm da mulher como alguém excessivamente cautelosa, é um estereótipo.

Não correr riscos nas organizações parece tratar-se de uma demanda organizacional mais do que um traço de personalidade feminina ou masculina, contrariamente aos dados obtidos pela pesquisa de Castro. ${ }^{39}$ Nesta amostra pode-se dizer que está descartada a idéia que os homens são mais ousados que as mulheres em suas decisões administrativas. Nas organizações, os riscos são previamente calculados.

\section{Sexualidade e sensibilidade femininas}

Os entrevistados, homens e mulheres, negaram a existência do uso da sexualidade, pela mulher, para a ascensão profissional. Admitem que nos níveis mais baixos até possa haver o uso da sexualidade. ${ }^{40}$
O não uso da sexualidade não significa ausência de uma certa erotização nas relações, entre os integrantes das organizações. ${ }^{41}$

Apesar de nas entrevistas os homens terem verbalizado que as mulheres executivas não fazem uso da sexualidade nas relações de trabalho, algumas mulheres entrevistadas afirmaram: "o homem tem medo que a mulher puxe o tapete (...) o homem tem medo de perder seu espaço para a mulher".

A interpretação da expressão "puxar o tapete" é a de que pode se tratar de ação fora das regras explícitas e negociadas do jogo de relações organizacionais. Se homens e mulheres têm recursos técnico-intelectuais em condições de igualdade para a competição dentro da organização, o que os homens podem temer? Qual é o elemento diferenciador na relação com a organização? A hipótese é a de que o elemento diferenciador é a sexualidade e o temor do uso indevido da mesma. Este temor talvez explique o surgimento de brincadeiras jocosas com tom sexual, por parte dos homens, como forma de defesa, principalmente quando estes perdem, na competição, para uma mulher. Esta defesa apresenta duas vertentes: ou a mulher conquistou os postos mais altos porque usou sua sexualidade, ou ela é um homem.

A fala do entrevistado ilustra esta idéia: "não há diferenças entre homens e mulheres executivos (...) a mulher para ser um bom profissional tem que ser um homem". Em outro momento, ele diz: "a mulher leva vantagens por ser mulher".

Essa perplexidade do entrevistado diante de alguém que é diferente e que faz sucesso gera

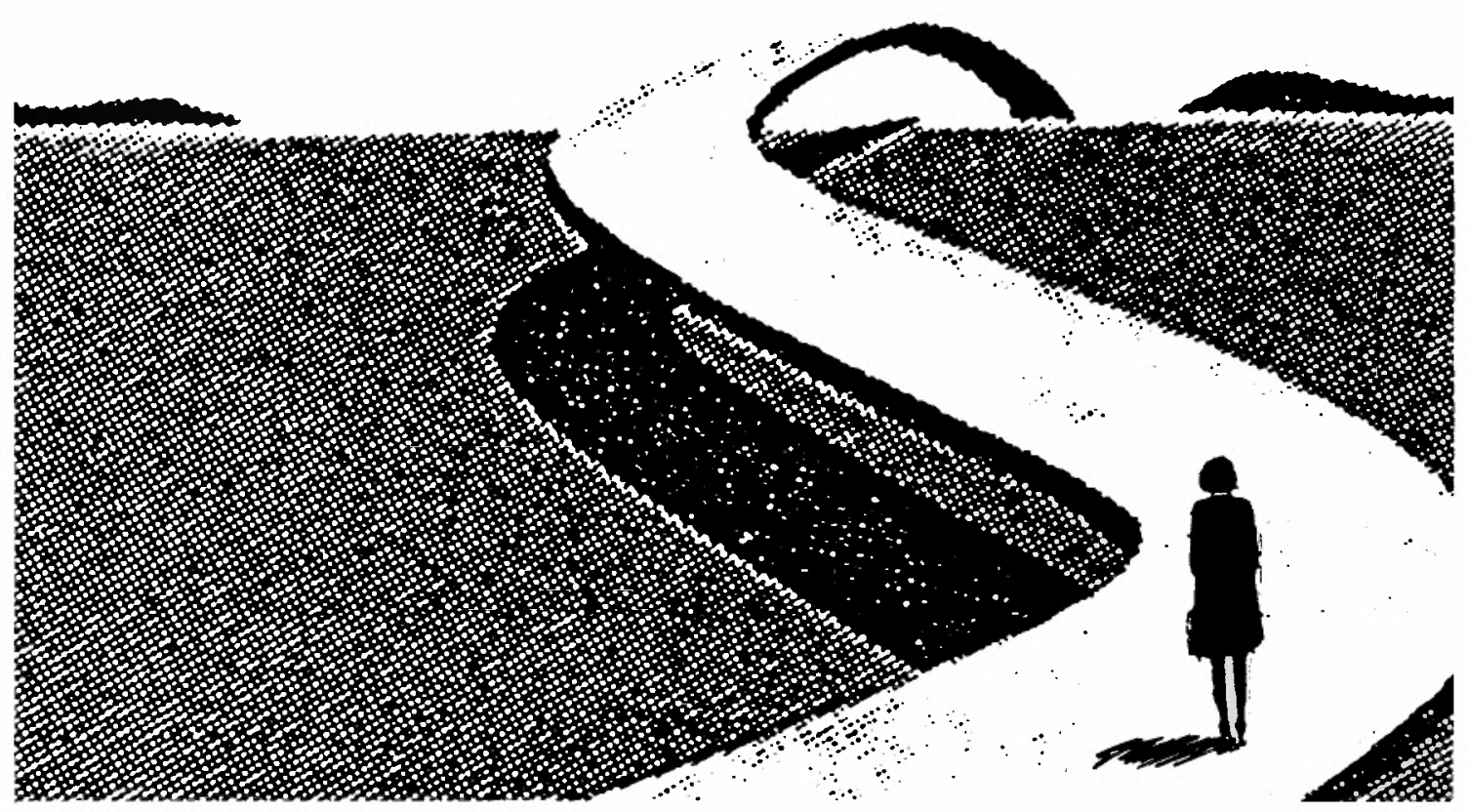


um discurso incongruente; aponta para a dificuldade de enfrentamento deste outro, do feminino, competindo como par na organização.

A mulher pode fazer uso da emoção e da sensibilidade femininas, mas não da sexualidade. Segundo um entrevistado, a presença da mulher no ambiente de trabalho "é salutar (...) a sociedade tem mulheres em todos os espaços sociais e o ambiente de trabalho fica mais equilibrado se as mulheres estiverem ai presentes". Compara a organização que só tem homens à "caserna".

A mulher na organização é importante, porque suaviza as relações, mas isto não quer dizer que o homem não fique impactado quando a mulher está disputando o poder com ele, e neste caso, talvez sem mesmo se dar conta, ele "prefira" que a mulher atue como "homem".

Todos os entrevistados, homens e mulheres, são unânimes em afirmar que a mulher consegue conciliar razão e emoção e que tem flexibilidade para lidar com pessoas e conflitos na organização. "O homem é mais rígido, a mulher é mais flexível". "O executivo de sucesso é aquele que tem chance, vontade e conhecimento, $\dot{e}$ aquele que gosta do que está fazendo e tem eficácia no que faz. A mulher tem mais sensibilidade do que o homem e isso pode gerar mais sucesso."

Se bem que os entrevistados não deixem claro, parece que a palavra sucesso se refere à habilidade nas relações interpessoais. Não obstante ser permitido à mulher o uso da "sensibilidade" e "emoção", estas têm limites dentro da organização. Segundo uma entrevistada "a mulher faz uso de uma forma mais delicada no trato interpessoal (...) esta forma de ser é positiva, pois facilita a obtenção do que se deseja dos outros, inibe uma negativa". A mulher tem consciência que faz uso deste traço, que é cultural, e o faz porque ele lhe traz vantagens.

A mulher não se coloca mais como vítima chorosa nas relações de trabalho, ainda que o poder não seja equitativo. Não é uma concessão do poder masculino que elas desejam, mas o reconhecimento da competência e a possibilidade de competir como igual. Segundo palavras de uma entrevistada "devemos fazer maior investimento do que os homens no trabatho, para superarmos preconceitos que ainda existem $^{\prime \prime}$. Apesar de não usar a palavra preconceito em relação ao trabalho da mulher, um entrevistado admite que as mulheres precisam fazer um investimento maior: "a mulher precisa fazer mais esforço do que o homem para mostrar competência e ser reconhecida". Este mesmo entrevistado diz: "quando investe no trabalho, a mulher faz tão bem ou melhor do que o homem", referindo-se ao trabalho e à competência da mulher executiva. Esse entrevistado afirma que aceita a mulher como igual mas se refere aos entraves que a organização em que trabalha coloca para a mulher.

É interessante notar que todos os homens entrevistados deixaram claro que eles não discriminam, mas que a organização o faz. Essas respostas dos entrevistados podem ser defesas psicológicas; talvez eles temessem serem avaliados como preconceituosos.

A idealização das habilidades da figura feminina, isto é, o uso da sensibilidade e da emoção sem perder a razão, discurso de um dos entrevistados, pode estar relacionada com a dificuldade que ele está passando no momento, em lidar com conflitos na organização.

Apesar de idealizar o papel da mulher executiva e aceitar sua competência profissional, acha "que a nossa sociedade ainda espera da mulher o cumprimento de um papel social de mãe, matriarca na familia". Segundo ele: "talvez não valha a pena muito investimento profissional da mulher (...) socialmente falando ela perde enquanto mulher, na familia, pois não pode estar em dois lugares ao mesmo tempo". Nota-se, novamente neste discurso, uma forma de esvaziar o próprio preconceito, através da projeção de seus sentimentos no coletivo.

\section{Investimento, dupla demanda e sucesso no trabalho feminino}

O desejo da mulher de igualdade de competição sofre sérias restrições: a questão da mobilidade geográfica e a dupla demanda, isto é, da familia e da organização. A mobilidade da mulher, tanto solteira quanto casada, se constitui num problema para as organizações. Viagens, compromissos fora da cidade e fora do horário de trabalho, principalmente se ela for casada e com filhos, é um forte fator impeditivo para a ascensão profissional. Acresce-se que a mulher, habitualmente, não desloca o marido e os filhos em função da demanda da empresa.

Na questão investimento no trabalho, homens e mulheres entrevistados concordaram que ele é diferenciado segundo sexo e estado civil. Na fala de uma das entrevistadas, "o investimento no trabalho é mais intenso para o homem. A mulher se restringe quando tem marido, casa e filhos. O homem leva vantagem no investimento que faz porque é mais livre para isso, até para se aprimorar, embora ambos tenham necessidade de aprimoramento."

Vários entrevistados citaram a obrigatoriedade de investir e fazer sucesso para o homem em contraposição à não obrigatoriedade de fazer sucesso por parte da mulher. Nas palavras de uma entrevistada: "o fracasso abate mais os homens. A mulher tem força, mais garra. Quando as 
42. MONAHAN, L.; KUHN, D. \& SHAVER, P. Op. cit.

43. OLIVEIRA, Rosiska. Op. cit. coisas não vão bem, a fragilidade do homem se externa de imediato". Essa entrevistada parece valorizar a garra e a força femininas em detrimento destas mesmas qualidades nos homens, por não considerar as pressões sociais a que os homens estão sujeitos para fazerem sucesso e, de outro lado, a pequena exigência de investimento e sucesso profissional para as mulheres.

Para um entrevistado, a mulher quando faz investimento é exceção: "a mulher, se está fazendo sucesso, é um lucro, é um fenômeno". Na avaliação masculina, o fracasso feminino tem peso menor, porque a mulher não tem obrigação de chegar lá em cima.

Quanto ao sucesso e fracasso profissionais, uma entrevistada diz que internamente é importante para ambos os sexos: "o fracasso dói da mesma maneira (...) mas, se a mulher falhar, socialmente as pessoas não encaram tão mal e para o homem é terrivel."

Quanto ao medo do sucesso, gerador da perda da feminilidade, como afirmam Monahan, Kuhn e Shaver ${ }^{42}$, referindo-se ao contexto americano, o resultado das análises desta pesquisa indica que o fracasso da mulher não está ligado ao medo do sucesso mas ao temor de deixar de cumprir um papel ainda fortemente prescrito de mãe e esposa, na cultura brasileira. Há, inclusive, respaldo social para o fracasso da mulher na organização e a volta ao lar.

\section{Contradições enfrentadas pelas mulheres nas organizações}

Uma das entrevistadas percebe dois modos de avaliação do trabalho pelos homens da organização em que está inserida. Um grupo, aqueles cujas esposas também trabalham fora, avalia de forma mais profissional o trabalho da mulher; outro grupo, cujas esposas não trabalham, tem ainda uma visão mais antiga sobre a mulher: "dondoca que quer ter o seu dinheiro para o supérfluo, para matar o tempo e quando tiver um filho certamente parará de trabalhar". Estes homens talvez não percebam a necessidade de realização profissional e pessoal das próprias esposas e generalizem esta avaliação preconceituosa para os pares da organização. Eles não conseguem enxergar o desejo da mulher.

A avaliação do desempenho profissional das mulheres por esses homens, independe da questão da competência feminina, mas está relacionada à sua vivência familiar.

Para um jovem entrevistado, "enquanto não houver um rearranjo cultural compartilhado por homens e mulheres, a mulher no trabalho conti-

trabalho e maternidade. As empresas acabam por preferir o certo por aquilo que, em sua ótica, seria duvidoso.

Ao mesmo tempo que há valorização do jeito feminino de lidar com conflitos, por exemplo, há dúvidas na empresa em colocar mulheres em posições estratégicas. Nota-se que há um clima até certo ponto contraditório, de abertura e desconfiança em relação à possibilidade de investimento efetivo da mulher no trabalho.

As incoerências percebidas ao longo dos discursos devem-se ao fato da sociedade viver um momento de transição e esta não se faz sem conflitos, choques e perplexidades.

Para a ascensão profissional da mulher, portanto, parecem existir ainda dois tipos de preconceitos: um, mais tradicional, que diz respeito às diferenças sexuais, pelo qual a empresa ainda vê a mulher como inferior e desigual, para assumir postos de comando; o outro, de empresas mais modernas, em que a discriminação é funcional, implicando em desconfiança da disponibilidade do investimento da mulher no trabalho. Parece que as empresas mais modernas já superaram a discriminação relativa às diferenças de competência entre os sexos.

A ambigüidade deste momento de transição é tão forte que, mulheres jovens em postos de comando ainda reproduzem estereótipos sociais. Uma entrevistada disse: "não trabalho com mulheres, elas são fofoqueiras e infantis". Apesar de repetir o estereótipo, se coloca fora dele: "eu visto gravata no trabalho". Ela se iguala aos homens e se considera diferente das mulheres da organização em que trabalha. Faz uma ruptura entre o masculino e o feminino, entre o adulto e o infantil dentro de si mesma: "no trabalho sou homem, em casa sou mulher, criança". No trabalho "visto gravata", em casa "sou bela adormecida".

A fala dessa entrevistada explicita o que Oliveira ${ }^{43}$ já havia apontado: a mulher tem que enfrentar mensagens contraditórias para ser respeitada; deve ser adulta, isto é, pensar e agir como homem no trabalho, emotiva e dependente, portanto infantil, em casa.

Provavelmente, o custo psíquico é acentuado para essas mulheres que enfrentam as contradições da organização e as conflitivas pessoais; porém, é inegável o enriquecimento pessoal obtido com a vivência dessas experiências.

\section{Relações do indivíduo com a organização} versos papéis: mãe, mulher e executiva".

Parece não ter havido ainda tempo hábil para a executiva provar que pode conciliar
A partir das falas dos entrevistados, notou-

\section{A administração do afeto}


se que as organizações na qual eles estavam inseridos eram por eles percebidas como possuindo nuances no tratamento dado a seus funcionários. Uma delas, com um ambiente de objetividade, frieza, competitividade e distanciamento afetivo, mas que impulsionava o desenvolvimento dos indivíduos na carreira e reconhecia seus méritos; outra, igualmente fria, competitiva, com distanciamento afetivo, burocrática, sem planos de carreira e que gerava insegurança em seus membros e, outra, ainda, de suporte emocional positivo para o bem estar de seus membros, mas não necessariamente de reconhecimento do valor do indivíduo e de suas reivindicações profissionais. Esta última, sem grandes desafios, mais satisfatória para os relacionamentos interpessoais, porém com menores possibilidades de crescimento em relação às empresas hipermodernas, no entanto assépticas quanto à afetividade. ${ }^{44}$

O que é reafirmado por todos os entrevistados que trabalham nas empresas hipermodernas e burocráticas é que a perda do controle emocional pode implicar em "fim de carreira". Nas organizações do tipo familiar, releva-se a perda do controle emocional ou, em certos casos, chega-se até a apoiá-lo. Uma das entrevistadas admite ser possível conjugar o mundo privado e o mundo profissional. Diz que é aceitável comentários sobre a vida privada na organização e se diz "muito maternal" com seus subordinados. Acha que essa característica não atrapalha: "é possível resolver problemas pessoais dentro da organização". Ao longo da entrevista, coloca em pé de igualdade os aspectos afetivos, emocional, social e profissional, não só para mulheres como também para os homens. Recebe respostas afetivas de reconhecimento, tanto por parte de seus subordinados como por parte de seus superiores.

A entrevistada exterioriza o lado afetivoemocional, mas esse tipo de organização não lhe dá espaço para crescimento e disputa por postos mais elevados. A inexistência dos mesmos impede uma disputa, uma ação concreta de luta pelo crescimento dentro da organização. Ela diz: "como eu tenho muito respaldo, muita segurança, então eu nunca tive medo de perder o meu lugar (...) isso fez com que eu me acomodasse".

Essa mistura de papéis, profissional e afetivo-emocional, é que parece dificultar uma definição profissional mais clara. Esse estilo paternalista parece gerar um tom queixoso na entrevistada, de dependência, de desejo que outros resolvam seus problemas profissionais.

Essa forma de relacionamento no trabalho contrasta com a forma de outros entrevistados que pertenciam a organizações hipermodernas e que investiam prioritariamente nas carreiras. Eles verbalizaram que a organização não admitia a dimensão afetiva-emocional. $O$ lado afetivo-emocional parece dificultar o investimento demandado pela organização. $O$ isolacionismo é uma política organizacional de controle dos indivíduos. A fala de um entrevistado evidencia este problema: "Amigos no trabalho não existem, existe companheirismo (...) O profissionalismo impede a amizade dentro do trabalho. Não se pode misturar relações pessoais com profissionais. Fazer esta separação entre o pessoal e o profissional é a forma mais fácil de se enfrentar a organização."

Encobrir o lado emocional é uma demanda da organização aceita pelos executivos, homens e mulheres, que devem estar inteiros na organização, priorizando o lado profissional de suas vidas. Uma fala feminina deixa clara esta visão: "a mulher executiva de sucesso precisa cindir, separar o pessoal do profissional em todos os sentidos da vida; precisa determinar o que ela quer $e$ batalhar tanto quanto o homem."

Nessas empresas, o clima é identificado como hostil e competitivo; não há espaço para amizade. Progredir é aceitar as regras do jogo empresarial.

A manutenção do controle emocional é uma exigência institucional forte, sentida pela entrevistada que acrescenta ser "o fim de carreira daqueles que não se controlam." Ela diz que se controla, aceita essa exigência "ainda que por dentro fique doente", quando recebe uma negativa institucional.

Um jovem entrevistado que trabalha numa empresa multinacional de origem européia diz que, apesar do descontrole emocional ainda ser mal visto na empresa, há uma tentativa de mudança da cultura e o descontrole passa a ser visto como uma possibilidade de aprendizagem e um conhecimento para o acerto. "A perda do controle emocional é vista como um erro, mas que tem a possibilidade de propiciar um aprendizado." Este não é o clima dominante na empresa, mas é uma "tendência", diz o entrevistado.

Se a empresa está tentando suportar o lado emocional dos indivíduos sem que isso signifique "fim de carreira", isto parece ser um avanço da organização hipermoderna; ao reconhecer que os executivos são seres humanos, pode propiciar maior flexibilidade nas organizações. ${ }^{45}$

Sobre o tema administração de conflitos, a hipótese é de que, como os executivos têm que conter a própria conflitiva, aparece, então, uma fantasia reasseguradora: se eu posso contê-los, eu posso administrar a conflitiva alheia. "Quem não sabe controlar a si próprio e às suas próprias emoçôes, teria dificuldade em controlar alguma coisa mais", diz um entrevistado.
44. Os entrevistados, ao se referirem às suas empresas, utilizaram as expressões: "multinacional moderna" "multinacional burocrática" e "pequena empresa brasileira administrada nos moldes de um grupo familiar. pelos sócios-proprietários". As expressões: hipermoderna, burocrática e tipo familiar, respectivamente, serão utilizadas para simplificação da linguagem. Apesar de que cada uma dessas denominacões implica em características muito específicas, este estudo não analisou diretamente os estilos de empresas, mas se restringiu às percepções dos entrevistados.

45. Convém ressaltar que as diferentes formas de atuação administrativa citadas para os modelos descritos de organização ("multinacional européia", "pequena empresa brasileira") podem estar também ligadas às diferenças de origem cultural de cada uma delas, como bem descrevem AMADO, G.; FAUCHEUX, C. \& LAURENT, A. "Changement Organisationnel et réalités culturelles Contrastes franco-américains". In: CHANLAT, Jean (coord.) L'individu dans lorganisation: les dimensions oubliées. Canadá, Les Presses de l'Université Laval e Editions ESKA, 1990. 
46. Segundo Bleichmar, "A alegria que experimenta 0 sujeito consigo mesmo quando se reconhece eficiente no exercício de uma atividade narcisada volta-se sobre os objetos que dela fazem parte: é o amor pela matemática da crianca que se considera dotada de habilidade para o cálculo, do terapeuta pela terapia, quando essa outorga-Ihe o trono desejado, do músico por seu instrumento na medida em que esse permitethe reafirmar seus dotes. Acaba-se por amar aquilo que faz a gente sentir-se amado (...) Ante a ausência dos objetos de atividade narcisista produz-se um profundo desequilibrio no sujeito, que pode conduzir à depressão, à irritação ou manifestar-se fenomenicamente como tédio (...) o que é vivido na consciência como um juizo sobre os objetos - isso eu gosto, aquilo me entedia -, na realidade são referências racionalizadoras em relação à colocada em jogo ou à ausência da atividade narcisista (...) 0 que começa sendo uma depressão narcisista, ou seja, um transtorno da satisfação com o ego, como representação unificada do sujeito, rapidamente transforma-se em desinteresse pelos objetos." Ver: BLEICHMAR, Hugo. O narcisismo: estudo sobre a enunciação e a gramática inconsciente. Porto Alegre, Artes Médicas, 1985, pp.30-3.
A contenção da própria conflitiva tem um custo e pode se exteriorizar pela via somática. Todos os entrevistados se referem a dois órgãos de choque do executivo: o estômago e o coração, que seriam os amortecedores da negação dos conflitos, além de suporte da carga psíquica e do stress decorrentes.

A administração de conflito parece ser diferenciada nas organizações tipo familiar e nas grandes organizações. As primeiras permitem a expressão das emoções e dão suporte aos conflitos pessoais e interpessoais. Quem administra nestas circunstâncias também se sente suportado e não isolado, ao contrário das grandes empresas.

Um dos entrevistados apresenta muitas dificuldades na sua relação com o trabalho, que é vivido como uma obrigação pesada e não como algo natural. Esse entrevistado já está na empresa há dez anos, tendo ingressado nela como estagiário. Ele diz: "A cultura organizacional vai invadindo o indivíduo". Ele se ressente de um clima rígido e autoritário. Um longo tempo de serviço numa empresa rígida parece enrijecer o indivíduo. Num clima organizacional autoritário, como o observado nesta entrevista, os sujeitos acabam por perder os parâmetros de suas possibilidades de ascensão, de satisfação de desejos, de expectativas futuras, de plano de carreira, planos que a própria empresa não divulga. Isto implica no embotamento da percepção que este indivíduo possa ter de seus desejos e dos desejos de seus subordinados. Do mesmo jeito que não vê reconhecidas suas necessidades profissionais, que leva a um desgaste, também não é capaz de avaliar as carências do pessoal de sua equipe, homens ou mulheres.

Ao enunciar o auto-controle como uma das características do executivo, dá a impressão mais de estar reprimido, o que dificulta sua tomada de consciência das dificuldades. Isto o impede de uma ação mais produtiva, bem como a possibilidade de compreender o próprio desejo e o desejo dos outros, quer no trabalho, quer fora dele. Perguntado sobre planos de carreira que a organização tem para ele, responde: "Taí uma coisa que eu gostaria de saber." Detecta alguns indícios de que há desejo da empresa no seu progresso, mas não tem certeza: "Suponho que haja interesse, pois a empresa me pagou o curso na GV, mas ela oscila. quanto à política administrativa, ao sabor das $m u$ danças de superintendências."

Esse clima organizacional é tão pesado que o impossibilita de exteriorizar qualquer desejo, de fazer o que gosta e o força a um ato de muito esforço, de desgaste na hora de se levantar e ir trabalhar. O desejo, "o que se gosta de fazer fica para a aposentadoria, na velhice".

Nesse clima autoritário, os projetos femininos também são diferenciados e pouco aceitos. Este é um modelo do passado que não dá espaço para mudanças. Os indivíduos inseridos nesta cultura podem assimilar essas idéias.

Por outro lado, se a estrutura psíquica dos indivíduos que se colocam dentro dessas empresas é portadora de um certo temor de mudança, isto gera uma complementariedade de papéis, isto é, o autoritarismo da organização e a submissão do indivíduo se completam. A mudança é vista por um entrevistado como catastrófica: "você muda, a empresa fale e você vai preso". De um lado, isto impede a saída dos indivíduos em busca de alternativas, de outro, a própria organização permanece imutável.

\section{Investimentos psíquicos}

A aparência física e a forma de se trajar são indicadores para a organização do grau de disposição e energia do indivíduo, no que resulta na valorização destes fatores pela mesma. Esses indicadores dizem respeito aos investimentos narcisistas sobre os objetos, que os indivíduos fazem: quanto maior o investimento, mais chances de progresso na organização. Uma entrevistada diz que para a mulher, a aparência é mais significativa ainda, é fundamental. A aparência é o primeiro impacto que mobiliza uma relação, porém deve ter conteúdo para que a relação positiva, principalmente a organizacional, se sustente. $O$ investimento não pode ser só físico para a mulher nem só intelectual para o homem; está havendo uma aproximação entre os dois sexos, no sentido de ambos estarem sendo avaliados nos dois âmbitos.

Para o trabalho, além da produtividade e competência é necessário um adequado investimento narcisista em si próprio. ${ }^{46} \mathrm{Os}$ indivíduos positivamente energizados são valorizados pela organização porque promovem um ambiente positivo e favorável ao grupo.

Entre os entrevistados, destacaram-se dois grupos, ambos compostos por homens e mulheres de posição hierárquica semelhantes, mas que se diferenciavam no comportamento. O primeiro grupo era composto de indivíduos positivamente energizados e que se avaliaram positivamente e também à organização a que pertenciam, havendo, ao que parece, uma reciprocidade de aceitação pela organização. $O$ segundo grupo se avaliava com menor positividade, apresentava uma fala mais depressiva e também não avaliava positivamente a organização, sentindo-se rejeitado por ela.

Duas hipóteses estão presentes para se entender esses processos: a primeira é que o pri- 

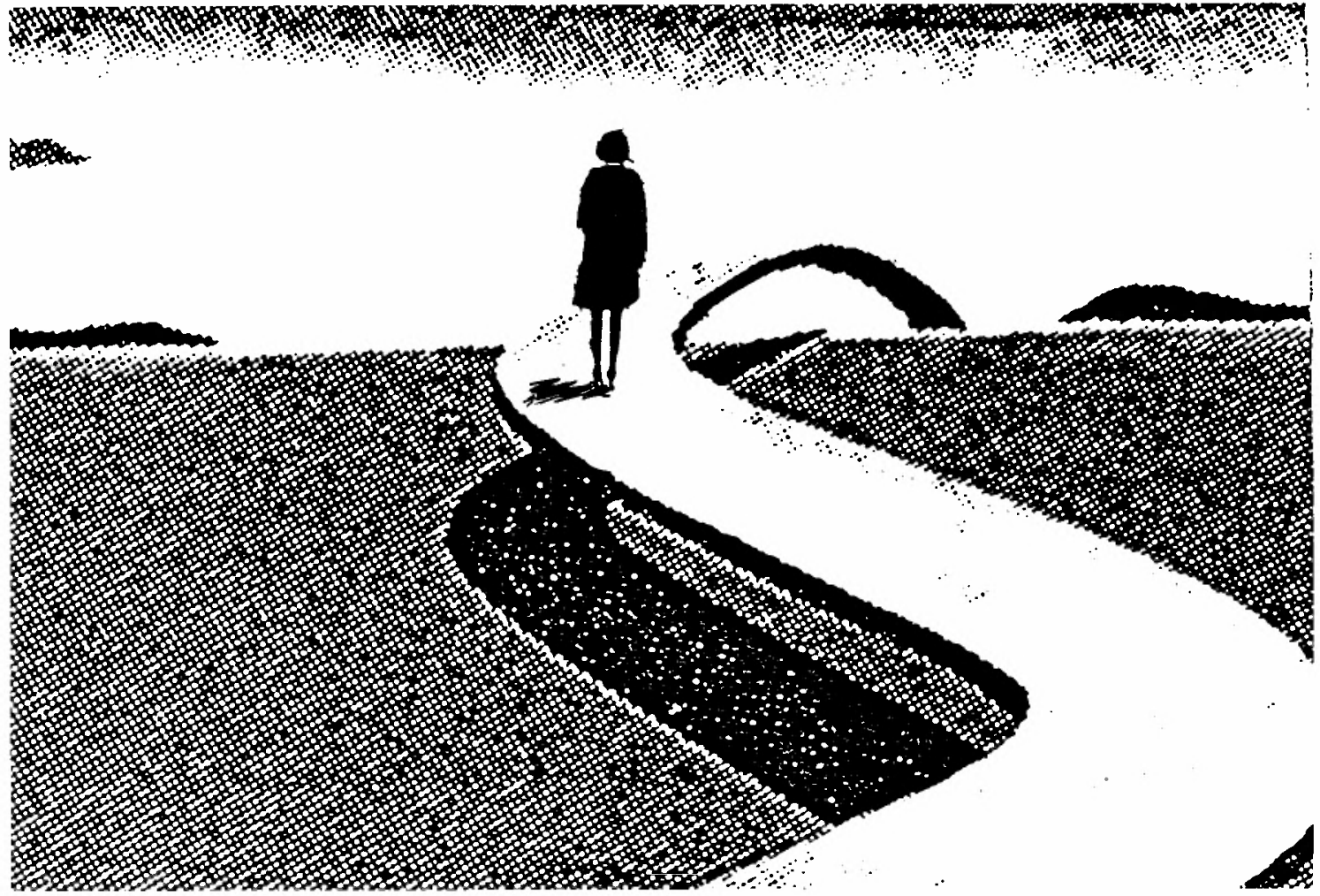

meiro grupo de indivíduos poderia estar avaliando corretamente os projetos que a organização possuía para eles. Neste caso, a reação positiva dos entrevistados era uma resposta à positividade da organização; no caso dos que se avaliavam negativamente, estariam respondendo a uma falta de projetos da empresa para eles. A segunda hipótese relaciona-se com características de personalidade de cada entrevistado. Neste caso, poderia estar havendo projeção na organização, da positividade ou negatividade, conforme desejos e estados de ânimo. Os homens e as mulheres do grupo mais energizado, tiveram com os entrevistadores um contato mais estimulante. Parece que essas pessoas tinham prazer em relatar as atividades de sucesso que estavam desenvolvendo.

Parece que um investimento narcisista nos objetos leva a uma energização das relações e dos atos, a tal ponto que há o reconhecimento da organização. Sem dúvida, um indivíduo energizado leva à frente projetos com o conseqüente reinvestimento da organização sobre eles.

Os indicadores externos dessa positividade aparecem na forma de se vestir e na forma de se relacionar. $O$ desleixo no vestir pode indicar um descuido consigo mesmo que não é adequado nem para o sujeito nem para a organização. O desleixo externo pode ter uma correspondência com uma desorganização interna, uma falta de confiança e auto-estima. A orga- nização, por sua vez, parece responder numa mesma linha de descrédito para esse sujeito.

Além da formação profíssional, da competência intelectual, da capacidade de trabalho, homens e mulheres têm que investir igualmente na aparência pessoal. Não se trata de beleza física, mas é uma questão de charme.

Uma das entrevistadas diz: "Parece coincidência, mas aqueles que tentam melhorar a aparência, se vestir melhor, investem um pouquinho mais nisto, são aqueles que realmente conseguem mais."

A palavra investimento usada pela entrevistada reflete o que se deseja apontar: o investimento é narcisista, para si e para a relação.

A simples presença com assiduidade e o cumprimento das tarefas atribuídas, sem um forte envolvimento energético não é suficiente para o progresso e o reconhecimento do executivo nas organizações.

Por vezes, essa imposição de trajar-se adequadamente acaba por se tornar apenas mais uma obrigação ligada à aparência, sem a correspondente dimensão interna de auto-estima. Isto faz com que alguns executivos confundam a possibilidade de sucesso profissional com a aparência externa; um entrevistado tem um estereótipo do que é ser um executivo: "éo boa pinta é um modo de se vestir que o distingue de outros profissionais..." Para esse entrevistado, outras atividades profissionais dentro da mesma organização não requerem "griffe" ao se vestir, não obstante terem conteúdo a oferecer. 


\section{Políticas organizacionais}

Na relação do indivíduo com a organização existe um "não dito", que é normatizador das condutas dos indivíduos, do modo de se vestir, da linguagem, do relacionamento interpessoal. É um não dito de origem dificilmente identificável, que sanciona regras que são obedecidas. Todos os entrevistados se referem a esse fato. Um deles diz: "Não sei quem iria falar se alguém viesse vestido de uma forma muito inusitada." Os homens devem vestir terno e gravata, as mulheres saias ou vestidos e não calças compridas. A exigência é de elegância discreta.

Outro tema abordado pelos entrevistados com unanimidade diz respeito à idade. Ela é vista como um empecilho para se alcançar postos de prestígio na organização. Com 45 anos já se é considerado velho. Nenhum dos entrevistados está situado nem mesmo próximo dessa idade considerada limite para a ascensão profissional. Trata-se de um temor de ser desprezado pela organização, pois muitos executivos, independentemente de sexo, ocupando postos de prestígio, já ultrapassaram essa idade.

As questões acima levantadas, tais como os "não ditos", a impossibilidade de exteriorizar sentimentos, o não esclarecimento do plano de carreira ou sua não existência, parecem levar a um esgotamento, a uma amargura. Talvez por isso, todos os entrevistados coloquem como data limite para o desenvolvimento dentro da empresa os 45 anos. Essa contínua situação sem saída gera uma carga psíquica elevada, que esgota. Todos dizem que aos 45 anos esperam ter diminuído este ritmo.

Essa sensação do indivíduo que já está há muito tempo na empresa e que vislumbra não suportar mais o ritmo a que está submetido é o que pode favorecer a aceitação da cultura organizacional, de extrema cobrança, competitiva, para os jovens de 25 anos que a vêem como positiva, geradora de progresso e a desilusão com que os entrevistados de 35 anos ou mais se referem à empresa e à perspectiva de carreira. Percebe-se que para esses entrevistados, a instituição aparece não mais como uma mola propulsora, mas como carga psíquica, depois de tantos anos de investimento.

O papel das políticas organizacionais é fundamental para o esclarecimento dos planos de carreira e redução da ansiedade. $\mathrm{O}$ executivo provavelmente não se sentirá excluído nem desmobilizado tão precocemente se houver clareza quanto à possibilidade de progresso, ainda que tenha que suportar uma certa carga psíquica.

\section{REFLEXõES FINAIS}

As transformações nas variáveis econômicas solicitaram o ingresso da mulher no mundo público, mantendo, no entanto, sua responsabilidade no âmbito doméstico. $O$ ingresso no mundo público foi sancionado, preferencialmente, para atividades cujas características exigiam atributos e habilidades socialmente consideradas como femininas. Esse sancionamento tem nuances que dependem dos diferentes extratos sociais, conforme estudo desenvolvido por Sulerot. ${ }^{47}$ As mulheres do nível econômico baixo e médio entram no mercado de trabalho por necessidade econômica tanto pessoal quanto familiar. Parece que essa passagem do mundo privado ao público ocorre mais facilmente quando ambos não se conflitam frontalmente. As mulheres de nível econômico privilegiado podem optar pelo trabalho. Essas mulheres estão buscando reconhecimento de competência e desejando competição entre iguais.

$O$ sucesso das mulheres nas organizações implica no redimensionamento do desempenho dos papéis tipicamente femininos, sem culpa. Acresce-se que para quem faz sucesso, a carga psíquica do investimento não é tão custosa, portanto ajuda a suportar a pressão da dupla demanda.

O sucesso da mulher depende, também, da cultura organizacional; empresas mais flexíveis facilitam o acesso da mulher. Os impedimentos que ainda são fortes, quanto à aceitação da mulher na organização, estão relacionados com as dificuldades da mobilidade geográfica e confiabilidade dos investimentos, ligados à dupla demanda.

O sucesso, porém, não é uma exigência social para a mulher. O retorno ao âmbito doméstico tem respaldo social, existindo a acolhida ao papel de origem, mãe e esposa. Tal não se verifica na esfera masculina. Os homens são impelidos à conquista, mesmo que isto não corresponda a um desejo profundo de ir à luta. Talvez o social veja, até com certo alívio, o retorno da mulher ao lar. O que geraria estranheza seria a troca de papéis: o homem fracassando no mundo público e assumindo o privado. A sociedade dá suporte ao fracasso feminino: ela pode voltar ao lar e ser só mãe.

Os entrevistados deixaram transparecer alguns desejos de homens e mulheres. A mulher desejando um mundo estimulante, cheio de contatos e dinâmico do trabalho fora do lar e menosprezando o que considera a mesmice da rotina doméstica - o sentimento de solidão e isolamento do lar. $O$ homem, por sua 
vez, invejando a posição da mulher no lar, tranqüila e segura, enquanto ele tem uma luta árdua no trabalho externo.

Mesmo, por vezes, apoiando a busca de trabalhos externos e sucesso da própria espo$\mathrm{sa}$, ainda assim alguns têm dificuldade em compreender as motivações profundas dessa busca. Fica nebuloso o motivo do abandono da segurança e tranqüilidade que ele deseja para si próprio, quando se encontra estressado pela competição organizacional.

Os homens sofrem pressão para o ingresso no mundo público, forte e clara; as mulheres dos extratos médios e superiores sofrem pressão velada para o ingresso, com respaldo para o abandono. Isto não significa, porém, ausência de sofrimento para as mulheres que fracassam e abandonam o trabalho; intimamente gera uma ferida narcisista.

As mulheres que hoje fazem sucesso foram aquelas que mostraram não só competência, mas foram avaliadas como confiáveis, pois investiram na organização, tiveram persistência num período de possível conflitiva entre as duas demandas e se encontram num período de estabilidade familiar, com decréscimo da exigência de uma das partes: a família. $O$ crescente número de mulheres de meia idade fazendo sucesso nas organizações parece ser explicado em função do tempo que todo esse investimento requereu.

Com relação ao medo do sucesso que a mulher teria, associado ao medo de perder a feminilidade, hipótese levantada por Monahan, Kuhn e Shaver ${ }^{48}$, nesta amostra tal não se verificou. A mulher sofre pressão social para cumprir um papel, mas não tem medo de perder a feminilidade.

Talvez ela tenha medo de, com o sucesso, perder o ambiente afetivo e positivo, anteriormente conquistado. Se o marido faz sucesso ele pode apoiar o sucesso da mulher e desta forma estará resguardado o espaço afetivo. Se o marido não faz sucesso, ele pode não suportar o desenvolvimento da mulher e, neste caso, seria uma aventura mais arriscada para a mulher que quisesse se lançar no mundo público. Provavelmente seja esta a razão dos investimentos diferenciados entre solteiras e casadas e que configura a característica afetiva da dupla demanda.

Quando a mulher investe no mundo público, obtendo alguma projeção e independência econômica, é possível que o homem não suporte tal situação e isso pode levar ao rompimento dos vínculos do casal.

A mulher, ingressando nas organizações, deverá reavaliar os investimentos que faz nos papéis femininos e isto exige uma capacidade de superação de papéis prescritos, sem medo ou culpa. O papel idealizado de docilidade feminina parece não ter espaço nas organizações, pelo menos para a atuação da mulher em postos de comando. As mulheres desta amostra afirmaram atuar segundo padrões masculinos de conduta. Para a ascensão profissional feminina pode ter mais peso a personalidade, o investimento e o tipo de organização, do que o fator sexo. Isto sugere que o ingresso da mulher no mercado de trabalho não alterou significativamente as relações organizacionais, pelo menos até o presente momento.

No que se refere aos temas tomada de riscos e uso da sexualidade, as falas dos entrevistados permitiram concluir que são estereótipos. Homens e mulheres correm riscos iguais dentro das organizações e ambos reconhecem que as mulheres que fazem sucesso, $o$ fazem pela competência e investimentos e não pelo uso da sexualidade. Não obstante atuarem segundo padrões masculinos, as entrevistadas afirmaram sentir discriminação; contrapondo-se à percepção feminina, os homens disseram que eles próprios não discriminam, só a organização o faz.

Apesar do reconhecimento da competência feminina, de seus investimentos e de sua atuação segundo padrões masculinos, elas continuam sendo mulheres, portanto diferentes, $\mathrm{e}$ isto assusta os homens. Talvez isto explique a persistência da discriminação.

Porém, para as novíssimas gerações que ingressam no mercado de trabalho, o nascimento do desejo de uma outra qualidade de vida tem recebido maior importância, numa tentativa de conciliar o mundo público e o privado, mais do que buscar sucesso e poder no público.

O objetivo não é só acumular fortunas, mas usufruir daquilo que se está obtendo. Buscase a possibilidade de uma vida privada prazerosa, mesmo com prejuízo de parte do poder e do prestígio. Vemos esse modo de inserção no mundo como uma dimensão positiva do narcisismo: o prazer não adiado, mas bem canalizado. Isto não significa que essa geração não esteja investindo no trabalho; há um constante investimento, porém aliado a um desejo de usufruir do mesmo.

Essa possibilidade é restrita a uma camada especial da população, que tem respaldo econômico e que pode fazer essa opção.

A geração mais velha parece indicar a esta mais nova que não é só investimento econômico que se deve fazer, mas múltiplos investimentos: afetivo, interpessoal, com preocupações ecológicas e sociais, que aumentem a qualidade de vida. $\square$
48. MONAHAN, L.; KUHN D. \& SHAVER, P. Op. cit. 